\title{
Out in the cold about COOL: An analysis of U.S. consumers' awareness of mandatory country-of-origin labels for beef
}

Katie L. Allen, ${ }^{\mathrm{a}, *}$ Courtney Meyers, ${ }^{\mathrm{b}}$ Todd Brashears, ${ }^{\mathrm{c}}$ and Scott Burris ${ }^{\mathrm{d}}$

Submitted 4 March 2011 / Accepted 12 May 2011 / Published online 10 July 2011

Citation: Allen, K., Meyers, C., Brashears, T., \& Burris, S. (2011). Out in the cold about COOL: An analysis of U.S. consumers' awareness of mandatory country-of-origin labels for beef. Journal of Agriculture, Food Systems, and Community Development, 1(4), $205-230$. http://dx.doi.org/10.5304/jafscd.2011.014.006

Copyright (C) 2011 by New Leaf Associates, Inc.

\begin{abstract}
Mandatory country-of-origin labeling (COOL) is a policy that requires a label noting what country or countries from which many fresh food products derive. While some have favored the policy as a marketing tool, others have criticized it as
\end{abstract}

a,* Corresponding author: Katie L. Allen, Marketing and Public Relations Assistant, American Angus Foundation, 3201 Frederick Avenue, Saint Joseph, Missouri 64506 USA; +1-816-383-5100; kallen@angus.org. Former graduate student, Texas Tech University, Lubbock, Texas, USA.

b Courtney Meyers, Assistant Professor, Texas Tech University, Box 42131, Lubbock, Texas 79409 USA;

+1-806-742-2816; courtney.meyers@ttu.edu

c Todd Brashears, Associate Professor, Texas Tech University, Box 42131, Lubbock, Texas 79409 USA; +1-806-742-2816; todd.brashears@ttu.edu

d Scott Burris, Associate Professor, Texas Tech University, Box 42131, Lubbock, Texas 79409 USA; +1-806-742-2816; scott.burris@,ttu.edu confusing, expensive, and difficult to mandate. An online survey of U.S. beef consumers who were their households' primary grocery buyers $(N=396)$ was conducted to examine their knowledge and awareness of COOL and the information sources they use to make food purchases. Only 10 respondents $(2.5 \%)$ knew COOL stood for country-of-origin labeling, and 287 respondents $(72.5 \%)$ indicated they had never heard of COOL. Despite an apparent lack of knowledge and awareness, a majority of the participants still supported the idea of mandatory COOL and preferred to have COOL for beef. The results indicated that more consumer education is needed about COOL. Further research is necessary to examine this policy as it diffuses among consumers.

\section{Keywords}

agricultural marketing, beef, consumer behavior, country-of-origin labeling, diffusion, food policy, labeling 


\section{Introduction and Literature Review}

When food shopping, consumers often look for distinguishing features, such as brands, labels, store signs, and unique packaging, to select one food item over the other (Schupp \& Gillespie, 2001). Food recalls and cases of food-borne illness have also influenced how consumers decide what to purchase. These issues have raised questions about the role of country-of-origin labels, traceability, and food safety inspections in shaping consumers' perceptions of food safety and quality worldwide (Loureiro \& Umberger, 2007).

In the United States, specifically, various agricultural and consumer advocacy groups have argued and pushed legislation for country-of-origin labeling (COOL). They claim such labeling may alleviate food safety concerns and garner support for U.S. products (Krissoff, Kuchler, Nelson, Perry, \& Somwaru, 2004). Srivastava (2003) reported three reasons the United States Department of Agriculture (USDA) considered mandatory traceability for food: (1) to protect consumers from fraud and producers from unfair competition, (2) to facilitate and monitor the food chain to enhance food safety, and (3) to address consumer information gaps about food safety and quality. The mandatory U.S. COOL program developed as a result of objectives such as these and created a system in which consumers can select and purchase foods based on where they come from, therefore giving them more buying power (Quittner, 2007).

U.S. lawmakers, with approval from the USDA, included legislation for mandatory COOL in the 2002 U.S. Farm Security and Rural Investment Act, or farm bill (Quittner, 2007). The provision in the bill required COOL for beef, lamb, pork, fish, perishable agricultural commodities, and peanuts by 2004. In January 2004, the implementation of mandatory COOL was delayed for all covered commodities aside from wild and farm-raised fish and shellfish until September 30, 2006. The mandatory implementation for these other commodities was again delayed in November 2005, and the extension was set to September 30, 2008 (USDA, 2008b).
The U.S. Food, Conservation, and Energy Act of 2008, known also as the 2008 Farm Bill, expanded the list of covered commodities in mandatory COOL to include chicken, goat meat, ginseng, pecans, and macadamia nuts (USDA, 2008b). Restaurants and other food-service providers are exempt from COOL, along with cooked, cured, smoked, and restructured meats (USDA, 2008a; Kay, 2008b). Lawmakers created the interim final ruling for mandatory COOL in the United States on August 1, 2008, and instituted that ruling on September 30, 2008.

The final mandatory ruling for COOL went into effect in March 2009 (Bjerga, 2009). The final rule outlined the requirements for labeling covered commodities and the record-keeping requirements for retailers and suppliers. A penalty was put in place for those who fail to follow the guidelines. Specific criteria determined if a product can bear a "United States country of origin" declaration, or if it must be labeled as foreign origin or have a multicountry-of-origin label (USDA, 2009a).

Prior to the implementation of mandatory COOL in the United States, studies found that consumers favored the idea of mandatory COOL and would be willing to pay more for COOL beef (Dickinson \& Bailey, 2005; Loureiro \& Umberger, 2003; Schupp \& Gillespie, 2001). Research has also shown that most consumers would prefer U.S.labeled beef over beef labeled from another country or labeled with a multicountry-of-origin label (Loureiro \& Umberger, 2003).

Mandatory COOL in the United States means more information for consumers on where their food comes from, but conversely the program has also drawn resistance from some food producers and agricultural leaders who say it requires too much time, work, and money in order to comply. In addition, implementing the program might have caused confusion among consumers when viewing food labels (Siegrist, 2009). Although many people have supported COOL, government officials, commodity and consumer groups, and the media have had differing viewpoints on the true purpose of the policy. According to Bjerga (2009), in 
January 2009, then U.S. Secretary of Agriculture Ed Schafer said COOL was implemented to market U.S. beef: "This is not a food safety issue. This is not a competitive issue or trade issue. This is a marketing issue. This is the ability of U.S. producers to label beef' (para. 8). The American Farm Bureau Federation (AFBF, 2007) also said that COOL is a marketing issue, but many people have perceived it as a food safety issue. In an article by Talbot (2009), COOL was addressed as a policy meant to help consumers protect their health by avoiding foods from certain countries when a health risk, such as salmonella, is reported there: "Advocates for food safety and individuals who care about the point-of-origin of the products covered celebrated the implementation of the law" (para. 6).

Another criticism of COOL is that the program is expensive to implement and maintain. The AFBF reported the program would cost between US $\$ 500$ million and US $\$ 3.9$ billion in its first year, and subsequent years were expected to run between US $\$ 140$ million and US\$600 million (AFBF, 2007). COOL opponents argue that the costs for a more accurate record-keeping system would be passed to the consumer and raise food prices (Krissoff et al., 2004).

Because the program requires more record keeping, U.S. beef and pork companies are either refusing to buy or are putting more emphasis on segregating cattle and hogs from outside the United States (Burgdorfer, 2009). In October 2009, officials from Canada and Mexico contacted the World Trade Organization (WTO), claiming that COOL was damaging North American trade (Lynn, 2009). Many livestock producers and industry experts say consumers do not care about the country of origin or pay attention to the labels, and the added cost of implementing the program is hurting the meat industry (Burgdorfer, 2009).

On average, a U.S. consumer eats 67 pounds of beef per year (Davis \& Lin, 2005). The USDA reported the retail value of beef in the United States in 2008 at US $\$ 76$ billion (USDA, 2009b). U.S. cattle feeders and meat packers, processors, and retailers have generally opposed required country-of-origin labeling (Krissoff et al., 2004). Due to costs associated with more record-keeping and segregating animals from different countries, mandatory COOL for the beef industry is expected to cost cattle producers US $\$ 9$ more per head, packers and wholesalers 1.5 cents (US) more per pound, and retailers about 7 cents (US) more per pound (Kay, 2008a).

The label for beef first lists the country where the animal was processed or slaughtered, and then retailers are responsible for listing other countries of origin on the label in alphabetical order (Kay, 2008b). In order to minimize costs, however, some food retailers are adopting a catch-all blanket label for beef, which includes a list of all the countries from which the product potentially could have come. This label is placed on all products, regardless of actual origin, so the use of the "Product of the United States" label for beef might be more limited than supporters of COOL had hoped. The USDA is combating this by requiring beef from the United States to be labeled as U.S. beef, rather than allowing a blanket label (Hagstrom, 2008).

\section{Theoretical Contribution}

Rogers' (2003) Diffusion of Innovations theory was applied in this study to help understand how information about labels diffuses through a system, and how consumers' knowledge about COOL influences their food purchases. Diffusion is defined as "the process in which an innovation is communicated through certain channels over time among members of a social system" (Rogers, 2003, p. 5). COOL is required by law, and therefore, is an authority-influenced innovation, which means that relatively few individuals in a system who possess power-in this case, U.S. lawmakers-make the decision for everyone in the social system to adopt the innovation.

\section{Purpose and Research Questions}

The purpose of this study was to explore U.S. beef consumers' knowledge and awareness toward country-of-origin labels following the implementation of mandatory COOL in the United States. The following research questions were used to guide 
the study:

RQ1. What are the demographic characteristics of the sample?

RQ2. What are the information sources consumers use to make food purchases?

RQ3. How aware are U.S. consumers of COOL?

RQ4. What are the relationships between selected consumer demographics, COOL awareness, and the information sources consumers use to make food purchases?

\section{Applied Research Methods}

This study used a descriptive survey design by means of a questionnaire administered online by Zoomerang $^{\mathbf{T M}}$ to a nationwide sample of U.S. primary household grocery buyers. The researchers were able to use Zoomerang to administer the questionnaire only to those people who indicated they were the primary grocery buyer for their household. Targeting a sample as specific as this on a national scale using any method other than online was not feasible, and might even have been impossible. According to Zoomerang (2010), its more than two million survey respondents are profiled using more than 500 demographic, lifestyle, occupational, and geographic attributes, which give researchers access to specific target groups, such as U.S. primary household grocery buyers. Therefore, the accessible population was individuals in Zoomerang's online survey panel who had indicated, on an extensive personal disclosure, that they are the primary grocery buyer for their household.

As this survey was a national assessment, the entire population of the United States was taken into account to determine sample size. The U.S. Census Bureau estimated the total U.S. population in December 2009 at more than 308 million (U.S. Census Bureau, 2009). According to the Krejcie and Morgan (1970) table for required sample size, a population size of more than 300 million requires a sample size of 384 participants with a $95 \%$ confidence, $5 \%$ margin of error. Zoomerang charges by the number of respondents, meaning that when a certain number is reached, access to the online questionnaire is closed. This method provided the specific, mutually exclusive quota sample of U.S. primary household grocery buyers the researchers needed.

The respondents were asked at the beginning of the questionnaire if they or anyone in their household consumed beef or other meat products. If the respondents answered "no," they were directed to complete the demographics section only, and their responses were not used when analyzing the results for this study. Only those people who indicated that they or someone in their household consumed beef were used to ensure the collected data were from beef consumers. A total of 413 people completed the online questionnaire before Zoomerang closed access. Of the completed questionnaires, 17 claimed to not be consumers of beef. Therefore, the sample used for this study included 396 respondents.

A researcher-developed questionnaire (see the full instrument in the appendix) was administered online to collect data to address the research questions. The instrument was tested for validity using a panel of university faculty experts and reliability using a pilot test of 30 participants before Zoomerang was used to administer the questionnaire to the sample. Reliability and validity were assessed online using the same method of administration as the actual survey to the respondents. The survey was conducted in the fall of 2009.

Once the survey was complete, data analysis was conducted using SPSS ${ }^{\circledR}$ version 17.0 for Windows. Demographic questions were analyzed using descriptive statistics, specifically measures of central tendency. The researchers found common themes when evaluating open-ended answers and calculated frequencies for the answers.

\section{Results}

RQ1: What are the demographic characteristics of the sample?

The sample for this study included 396 respondents. Demographic questions asked participants 
to disclose or classify a number of characteristics. The items reported in this paper are gender, age, highest level of education obtained, state of residence, estimated annual household income, ethnicity, and level of involvement in the beef industry and agricultural industry. More females $(n=268$, $67.7 \%$ ) responded to the survey compared to males $(n=128,32.3 \%)$. Respondents' ages ranged 66 years, from age 18 to age 84 , with a mean age of $48.63(S D=14.33)$. While education ranged from less than a high school education $(n=4,1 \%)$ to a doctorate degree $(n=6,1.5 \%)$, most respondents indicated they had some college education $(n=$ $115,29 \%)$ or a bachelor's degree $(n=100,25.3 \%)$.

Respondents reported residing in 42 U.S. states. The largest number of respondents said they reside in California $(n=75,18.9 \%)$, followed by Texas $(n$ $=34,8.6 \%)$, and New York $(n=30,7.6 \%)$. The eight states not represented by the sample included Alaska, Idaho, Maine, Nevada, New Hampshire, North Dakota, Rhode Island, and South Dakota. Income levels ranged from less than US $\$ 15,000$ annually to more than US $\$ 105,000$ annually, with the largest number of respondents making between US $\$ 45,000$ and US $\$ 59,000$ per year $(n=69$, 17.4\%). Most survey respondents were Caucasian $(n=332,83.8 \%)$, followed by Hispanic $(n=20$, $5.1 \%)$, African American $(n=17,4.3 \%)$, Asian American $(n=16,4 \%)$, Other $(n=10,2.5 \%)$, and Native American $(n=1,0.3 \%)$. Respondents were asked to rate their level of involvement in the agricultural industry and the beef industry on a fivepoint Likert-type scale $(1=$ not at all, $5=$ quite a lot $)$. Overall, respondents indicated they have a fairly low involvement in both the agricultural industry $(M=1.62, S D=1.03)$ and beef industry $(M=$ $1.54, S D=0.94)$.

\section{RQ2: What are the information sources consumers use to make food purchases?}

Research question two sought to analyze the sources of information used to make foodpurchasing decisions. Participants could check off all the resources they use on a provided list (family and friends, Internet, newspaper, magazine, radio, supermarket advertisement, and television). They could also disclose other resources they use that were not on the provided list. Consumers indicated they receive information from many different places when making food purchases. Supermarket advertisements were used by the largest percentage of respondents $(n=244,61.6 \%)$. Half of the respondents $(n=198,50 \%)$ said they also get information from family and friends. Traditional information sources were also mentioned: newspaper $(n=122,30.8 \%)$, Internet $(n=105,26.5 \%)$, television $(n=98,24.7 \%)$, magazine $(n=55$, $13.9 \%)$, and radio $(n=21,5.3 \%)$. In addition to the provided responses, 40 respondents $(10.1 \%)$ said they used other sources of information to make food-purchasing decisions, including personal experiences $(n=11,2.8 \%)$, the store itself and its employees $(n=10,2.5 \%)$, and the product labels $(n=4,1 \%)$.

\section{RQ3: How aware are U.S. consumers of COOL?}

The intent of research question three was to determine the knowledge and awareness levels consumers have of COOL. The first survey question asked participants if they knew what COOL stands for in regard to food buying to initially assess knowledge of COOL before it was explained in further detail later in the questionnaire. Seventy-three respondents $(18.4 \%)$ said they did know what COOL stands for, while $323(81.6 \%)$ said they did not know. Respondents were then asked to provide an explanation of what COOL stands for. Of the 72 respondents who elaborated, $10(2.5 \%)$ reported COOL stands for country-of-origin labeling. Most respondents ( $n=47,11.2 \%$ ) who elaborated said COOL was related to temperature or keeping products cold, refrigerated, or frozen.

Later in the questionnaire, respondents were asked if they have ever noticed the country-of-origin label on their purchased beef products, and 110 respondents $(27.8 \%)$ said yes, while 286 respondents $(72.2 \%)$ said no. Respondents were then asked to explain where they had seen the country-of-origin labels located on the products. Of the 112 respondents who elaborated, the largest number of respondents $(n=24,21.4 \%)$ said they had seen the country-of-origin label on the front of the package, 20 respondents $(17.9 \%)$ said on the backside or bottom of the package, and $11(9.8 \%)$ said the label 
was somewhere on the package in fine, small, or hard-to-read print. Thirteen respondents $(11.6 \%)$ did not recall exactly where the country-of-origin label was located, and nine respondents (8\%) reported seeing the label in many different places, including the top and bottom of the package and on the store meat case.

All 396 respondents were also asked to think about the last beef product they purchased, and then to indicate from which country or countries that product originated, using a list that included the United States and its top 10 beef importers, based on importer data from the USDA (2010) (see table 1). The respondents could check all the countries that applied, given that their last purchased beef product could have had a multicountry-of-origin label. Twelve respondents indicated at least one country of origin for their last purchased beef product and also selected “don't know."

When asked to check all the resources that provided them with information about COOL, most respondents said they had not heard of COOL $(n=287,72.5 \%)$. If respondents had heard of COOL, the most common resource was the Internet $(n=36,9.1 \%)$. Table 2 provides the frequencies and percentages of each source.

Table 1. Country-of-Origin for Last Beef Product Purchased by Respondents ( $N=396$ )

\begin{tabular}{lcc}
\hline Country & Frequency & Percentage \\
\hline United States & 216 & $54.5 \%$ \\
Don't know & 179 & $45.2 \%$ \\
Canada & 11 & $2.8 \%$ \\
New Zealand & 9 & $2.3 \%$ \\
Mexico & 8 & $2.0 \%$ \\
Argentina & 6 & $1.5 \%$ \\
Australia & 4 & $1.0 \%$ \\
Brazil & 2 & $0.5 \%$ \\
Costa Rica & 1 & $0.3 \%$ \\
Honduras & 1 & $0.3 \%$ \\
Nicaragua & 1 & $0.3 \%$ \\
Other & 1 & $0.3 \%$ \\
Uruguay & 0 & $0.0 \%$ \\
\hline
\end{tabular}

Note. Mode $=$ United States. Respondents could check multiple answers; percentages do not equal $100 \%$.
Twelve respondents provided other resources for COOL not included in the list. The most common other response was that this survey was the first time they had heard of COOL $(n=4,1 \%)$.

When asked if they had heard of mandatory country-of-origin labeling in the past year, 381 respondents $(80.3 \%)$ said they never heard of mandatory COOL. Fifty respondents $(12.6 \%)$ said they had heard of COOL once, 21 respondents $(5.3 \%)$ had heard of COOL $2-5$ times, and seven respondents $(1.8 \%)$ had heard of COOL more than five times. On a five-point Likert-type scale $(1=$ not at all, $5=$ quite a lot $)$, respondents indicated they were not very aware of labeling policies for beef $(M=2.17, S D=1.08)$ and even more unaware of COOL for beef $(M=1.76, S D=1.07)$.

After analyzing initial awareness of country-oforigin labeling, the questionnaire asked participants to rank the importance of having a country-oforigin label on four commonly purchased beef cuts (ground beef, roast, steak, and stew meat) using a five-point Likert-type scale $(1=$ not at all, $5=$ very $)$. Respondents consistently put a relatively high importance on having a country-of-origin label on all beef cuts: ground beef $(M=4.25, S D=1.02)$, roast $(M=4.19, S D=1.01)$, steak $(M=4.23, S D$ $=1.00)$, and stew meat $(M=4.18, S D=1.05)$.

\section{Table 2. Resources Providing Information About $\operatorname{COOL}(\mathrm{N}=396)$}

\begin{tabular}{lcc}
\hline Resource & Frequency & Percentage \\
\hline Have not heard of COOL & 287 & $72.5 \%$ \\
Internet & 36 & $9.1 \%$ \\
Don't know & 25 & $6.3 \%$ \\
Television & 24 & $6.1 \%$ \\
Family/Friends & 21 & $5.3 \%$ \\
Newspaper & 19 & $4.8 \%$ \\
Supermarket & 13 & $3.3 \%$ \\
advertisement & 12 & $7.8 \%$ \\
Other & 10 & $2.5 \%$ \\
Radio & 9 & $2.3 \%$ \\
Magazine & & \\
\hline
\end{tabular}

Note. Mode $=$ Have not heard of COOL. Respondents could check multiple answers; percentages do not equal $100 \%$. 
Two open-ended questions asked what mandatory country-of-origin labeling means to the participants personally and what the participants believe is the government's purpose for implementing countryof-origin labeling in the United States. The researchers categorized common responses to the questions, and frequencies were determined. Six of the open-ended responses could not be categorized due to the inability to interpret those responses or to fit them in the emergent categories, so percentages do not equal $100 \%$. Analysis of these openended answers found that most respondents said mandatory country-of-origin labeling just told them what country or countries the product was from, nothing more $(n=111,28 \%)$. Sixty-three respondents $(15.9 \%)$ said COOL calls for more responsibility of beef producers, packers, retailers, importers, and the U.S. government, and 50 respondents $(12.6 \%)$ said they did not know or did not understand COOL. Other open-ended responses included: provides more information and more choices when buying food $(n=45,11.4 \%)$, makes food more safe $(n=44,11.1 \%)$, nothing or apathetic towards COOL $(n=41,10.4 \%)$, made more aware of COOL after this survey $(n=13$, $3.3 \%)$, keeps foods fresh or cold $(n=8,2 \%)$, COOL is important $(n=8,2 \%)$, COOL is not important $(n=4,1 \%)$, and I will only buy U.S. beef $(n=3,0.8 \%)$.

The next open-ended question asked what the participants believed was the purpose of the government in implementing mandatory countryof-origin labeling in the United States. Nine of these responses could not be categorized, so percentages do not equal 100\%. The largest portion of respondents said they believed the decision to implement mandatory COOL was made to increase consumer awareness of where their products originate $(n=$ $113,28.5 \%$ ), while the second most frequent response was that they believed the government implemented COOL to protect consumers from diseases and contaminated foods and to keep consumers safe $(n=102,25.8 \%)$.
Other open-ended responses included: don't know or unsure $(n=52,13.1 \%)$, provides more choices when buying food $(n=46,11.6 \%)$, nothing or apathetic towards the purpose $(n=19,4.8 \%)$, promotes U.S. beef over foreign beef $(n=17$, $4.3 \%)$, confuses consumers $(n=10,2.5 \%)$, ensures higher-quality foods $(n=8,2 \%)$, keeps foods fresh or cold $(n=8,2 \%)$, provides a good or important program $(n=5,1.3 \%)$, provides better tracking and inspections for food $(n=4,1 \%)$, and requires more truthful information on label packages $(n=3$, $0.8 \%)$.

\section{RQ4: What are the relationships between selected consumer demographics, COOL awareness, and the information sources consumers use to make food purchases?}

Correlations were performed to determine the relationships between selected demographics, COOL awareness, and the information sources consumers use to make food purchases. The strength of the relationships was reported based on Davis (1971), where 1.00 is a perfect relationship, $.70-.99$ is a very high relationship, .50-.69 is a substantial relationship, .30-.49 is a moderate relationship, .10-.29 is a low relationship, and .01-.09 is a negligible relationship. Significant relationships found at .05 a priori are noted within the tables.

Table 3 shows the relationships between selfperceived involvement in the agricultural and beef industries and respondents' self-perceived knowledge of what COOL stands for, as well as self-perceived awareness of both labeling policies in general and COOL for beef. All relationships in

\section{Table 3. Relationships Between Industry Involvement and Knowledge/Awareness}

\begin{tabular}{lcc}
\hline Characteristic & $\begin{array}{c}\text { Agricultural } \\
\text { industry } \\
\text { involvement }\end{array}$ & $\begin{array}{c}\text { Beef industry } \\
\text { involvement }\end{array}$ \\
\hline Knowledge of what COOL stands for $\left(r_{p b}\right)$ & $.12^{*}$ & $.11^{*}$ \\
Awareness & $.52^{*}$ & $.55^{*}$ \\
Labeling policies for beef $(r)$ & $.54^{*}$ & $.53^{*}$ \\
COOL for beef $(r)$ &
\end{tabular}

Note. ${ }^{*} p<.05$. 
Table 3 are positive and significant. Knowledge of what COOL stands for and industry involvement showed low relationships, while awareness of COOL and labeling policies and industry involvement showed substantial relationships.

Table 4 shows the relationships between information sources used for COOL and agricultural and beef industry involvement. All relationships are low; however, "have not heard of COOL" and agricultural $\left(r_{p b}=-.20\right)$ and beef industry $\left(r_{p b}=-.20\right)$ involvement are the only negative relationships reported. The relationships were significant at alpha level .05 for both agricultural and beef industry involvement and the following items: have not heard of COOL, family/friends, Internet, newspaper, magazine, and radio. The strongest associations were between agricultural $\left(r_{p b}=.35\right)$ and beef industry $\left(r_{p b}=.29\right)$ involvement and use of magazines as a resource for COOL.

Table 5 shows the relationships between sources of information, awareness of labeling policies, and awareness of COOL. There was a low, negative correlation between perceived knowledge of COOL and "have not heard of COOL" $(\varphi=$ -.17), which was significant at alpha level .05 and was the only negative relationship in the column. The relationship between awareness of labeling policies and "have not heard of COOL" was a low, negative relationship $\left(r_{p b}=-.25\right)$ significant at alpha level .05. The relationship between "have not heard of COOL" and perceived awareness of COOL was a moderate, negative relationship $\left(r_{p b}=-.41\right)$ significant at alpha level .05. The other information sources showed positive relationships with perceived knowledge and awareness variables, and many were significant at alpha level .05. Awareness of
COOL overall had stronger relationships with the information sources for COOL.

\section{Conclusions and Recommendations}

First, twice as many women responded to the survey, but it was expected that more women would respond as the study targeted primary household grocery buyers. In Loureiro and Umberger's (2003) study of COOL, they found that females are most often the household grocery shoppers. Respondents in the current study were primarily Caucasian $(n=332,83.8 \%)$. This is not representative of the U.S. population, which according to the latest census is $75.1 \%$ Caucasian (U.S. Census Bureau, 2002). Respondents' ages
Table 4. Relationships Between Industry Involvement and Information Sources Used for COOL

\begin{tabular}{lcc}
\hline Information source & $\begin{array}{c}\text { Agricultural Industry } \\
\text { Involvement }\left(r_{p b}\right)\end{array}$ & $\begin{array}{c}\text { Beef Industry } \\
\text { Involvement }\left(r_{p b}\right)\end{array}$ \\
\hline Don't know & .07 & .06 \\
Have not heard of COOL & $-.20^{*}$ & $-.20^{*}$ \\
Family/Friends & $.23^{*}$ & $.23^{*}$ \\
Internet & $.20^{*}$ & $.22^{*}$ \\
Newspaper & $.18^{*}$ & $.17^{*}$ \\
Magazine & $.35^{*}$ & $.29^{*}$ \\
Radio & $.19^{*}$ & $.18^{*}$ \\
Supermarket advertisement & $.08^{*}$ & .12 \\
Television & .03 & .03 \\
\hline
\end{tabular}

Note. * $p<.05$.

Table 5. Relationships Between Knowledge/Awareness and Information Sources Used for COOL

\begin{tabular}{lccc}
\hline Information source & $\begin{array}{c}\text { Knowledge } \\
\text { of COOL }(\varphi)\end{array}$ & $\begin{array}{c}\text { Awareness } \\
\text { of Labeling } \\
\text { Policies }\left(r_{p b}\right)\end{array}$ & $\begin{array}{c}\text { Awareness } \\
\text { of COOL }\left(r_{p b}\right)\end{array}$ \\
\hline Don't know & .04 & .05 & $.12^{*}$ \\
Have not heard of COOL & $-.17^{*}$ & $-.25^{*}$ & $-.41^{*}$ \\
Family/Friends & $.18^{*}$ & $.22^{*}$ & $.30^{*}$ \\
Internet & $.17^{*}$ & $.23^{*}$ & $.33^{*}$ \\
Newspaper & $.20^{*}$ & $.16^{*}$ & $.26^{*}$ \\
Magazine & $.23^{*}$ & $.29^{*}$ & $.37^{*}$ \\
Radio & $.21^{*}$ & $.18^{*}$ & $.29^{*}$ \\
Supermarket advertisement & .06 & $.20^{*}$ & $.17^{*}$ \\
Television & .07 & $.13^{*}$ & $.27^{*}$ \\
\hline
\end{tabular}

Note. * $p<.05$. 
were more diverse, ranging 66 years, with a mean age of 48.63 ( $S D=14.33)$, which is above the U.S. average age of 35.3 years. Education level was also diverse, as it ranged from less than a high school education to a completion of a doctorate degree, with most respondents indicating they had some college education $(n=115,29 \%)$ or a bachelor's degree $(n=100,25.3 \%)$. The latest U.S. Census showed $21 \%$ of U.S. citizens having some college education but no degree, and $15.5 \%$ holding a bachelor's degree. The sample, therefore, had obtained slightly more education overall compared to education levels of the U.S. population. Respondents' residences represented 42 of 50 U.S. states. Income levels were comparable to the latest U.S. Census data. The largest proportion of respondents $(17.4 \%)$ indicated that they make between US $\$ 45,000$ and US $\$ 59,000$ per year. The latest U.S. Census showed the largest proportion of people $(19.5 \%)$ made between US $\$ 50,000$ and US $\$ 74,000$ annually. Respondents indicated overall that they had low involvement in agriculture and the beef industry. This is not surprising because so few people in the United States remain directly involved in agricultural production.

At the beginning of the questionnaire, participants were asked if they knew what COOL stands for in regards to food-buying. Only $10(13.7 \%)$ reported that COOL stands for country-of-origin labeling, while $47(64.4 \%)$ said COOL was related to temperature or keeping products cold, refrigerated, or frozen. It was evident respondents did not know what the COOL acronym stands for or were confused by the question. Nearly three-quarters of the respondents said they had not noticed the countryof-origin label before when purchasing beef products. Respondents who had noticed the label reported seeing country-of-origin labels in many different and inconsistent places on the beef products, such as the top or bottom of the package. These differences could be attributed to the fact that the exact location of the country of origin on the label package is not mandated and therefore is inconsistent.

When asked to indicate from which country or countries the last beef product they purchased had originated, most respondents reported the United States or that they did not know. More respondents indicated their last beef product originated in the United States $(n=216)$ than the number of respondents who said they had noticed the country-of-origin label $(n=110)$ on the last beef product they purchased. Perhaps some of the respondents simply assumed their last product purchased was a U.S.-origin product.

Most respondents said they had not heard of country-of-origin labeling $(n=287,72.5 \%)$. If respondents had heard of COOL, the data showed they used a combination of interpersonal and mass media resources to find out about COOL. Although supermarket advertisements were the most utilized resource for making food purchases, very few respondents heard about COOL from a supermarket advertisement. Interestingly, a few respondents said the survey they were completing was the first time they had heard of COOL.

Despite the variance in the information sources used to find information about COOL, most respondents admitted they were still unaware of the policy more than 11 months after it was implemented in the United States. Although most respondents had not heard of COOL and were not aware of the label on their beef, they still put a relatively high importance on having the label on their ground beef, roast, steak, and stew meat.

As self-reported involvement in the agricultural and beef industries increased, self-perceived knowledge of what COOL means also increased; therefore, those with more involvement in agriculture and beef were more likely to say they knew what COOL stood for and the more they believed they knew about COOL for beef and beef labeling policies. When examining the relationships between sources used to get information about COOL and respondents' involvement in the agricultural and beef industries, the use of magazines to get information about COOL showed the strongest relationship with agricultural and beef industry involvement. This indicates that people involved in the agricultural and beef industries were more apt to hear about COOL from a maga- 
zine. Prior studies have found that people involved in agriculture rely on farm publications for information (Ford \& Babb, 1989; Wadud, Kreuter, \& Clarkson, 1998; Naile, 2006).

The sample used in this research study was a quota sample of primary household grocery buyers, so results cannot be inferred to the entire population of U.S. primary household grocery buyers. Overall, respondents in this study were not very knowledgeable or aware of COOL, but they still believed COOL is an important concept. Respondents' level of perceived awareness of beef labeling policies and COOL for beef was also low. Answers to open-ended questions regarding respondents' beliefs as to the purpose of COOL were varied. According to Rogers' (2003) diffusion theory, complexity adversely affects the adoption of an innovation in a social system. The contradictory statements about the purpose of COOL from the Department of Agriculture and farm organizations, likely shared through food safety and food industry mass media news, have led to the many interpretations of COOL by the respondents of this survey, generated more complexity in the issue, and have indeed generated confusion among consumers. These findings justify the need for practitioners to provide a more accurate description of COOL in their communication efforts. Policy and industry leaders alike need to provide a more focused description of the policy when working with the media and in their own communications.

Once a more uniform message is developed about COOL and labeling is consistent on food products, consumer understanding of COOL will likely increase. If COOL is meant to be a marketing tool for U.S. products, the USDA should consider an extensive marketing campaign for U.S. products such as one implemented in Australia (see Juric \& Worsley, 1998). Policy-makers and -implementers need to be aware that marketing U.S. products is not likely to help alleviate trade barriers produced by COOL, especially with the United States' North American trade partners already reporting a decline in their U.S. exports. Communicators should focus on the most utilized communication outletssupermarket advertisements and family and friends - to provide consumers with more information about COOL for beef. This might make consumers more knowledgeable and aware of COOL, but perhaps more importantly, it can also help clarify the purpose of the policy and decrease the amount of confusion.

This study focused strictly on beef, while COOL applies to a wide variety of other fresh foods; therefore, there are many opportunities to study COOL as it relates to other food products. Furthermore, COOL could be studied in greater detail using qualitative methods to make more sense of consumers' knowledge, awareness, and perceptions of COOL and how these factors motivate food purchases. Regional studies using focus groups, interviews, or other qualitative methods might provide more understanding of how consumers from specific areas relate to COOL. More research also needs to be performed looking at how COOL is portrayed in a variety of information sources. As shown in this study, consumers use many different methods to obtain information, and the information they have received about the purpose of COOL has been contradictory. A closer examination of consumer perceptions of COOL and the information sources they utilize is needed, as COOL policy could be adjusted based on the concerns of consumers, the food marketing chain, government and political leaders, and the vital world trade partners of the United States.

This study looked at factors relating to COOL from the perspective of the U.S. primary household grocery buyer. These people are an influential part of the food chain, because they generate demand for particular food products. This study found that while this sample of household grocery buyers believed COOL is important, they did not know much about it and what it truly means close to a year after COOL was mandated. As COOL diffuses into the marketing system, more people might become more knowledgeable about it and use it to make food purchases. In addition to consumers, many others in the food marketing chain have been affected by COOL. Farmers, processors, marketers, handlers, consumers, governments, and the general public have stakeholder interests in the 
safety and cost-effectiveness of global agri-food supply chains (Opara, 2003). Quantitative and qualitative studies focusing on knowledge and awareness, perceptions, and behaviors of farmers, processors, packers, and retailers in the beef industry would provide an even broader understanding of how to work through the issues that COOL in the United States brings to the table both literally and figuratively.

\section{References}

American Farm Bureau Federation (AFBF). (2007). COOL executive summary. Retrieved from http://www.kfb.org/commodities/ commoditiesimages/COOL\%20AFBF.pdf

Bjerga, A. (2009, January 12). Final U.S. country-oforigin labeling rule draws criticisms. Bloomberg. Retrieved from http://www.bloomberg.com

Burgdorfer, B. (2009). New label law shakes up meat industry. Reuters. Retrieved from http://www.reuters.com/article/ idUSTRE53705G20090408

Davis, C.G., \& Lin, B.H. (2005). Factors affecting U.S. beef consumption. Retrieved from http://www.ers.usda.gov/publications/ldp/Oct05/ ldpm13502/ldpm13502.pdf

Davis, J.A. (1971). Elementary survey analysis. Englewood, NJ: Prentice-Hall.

Dickinson, D.L., \& Bailey, D. (2005). Experimental evidence on willingness to pay for red meat traceability in the United States, Canada, the United Kingdom, and Japan. Journal of Agricultural and Applied Economics, 37(3), 537-548.

Ford, S. A., \& Babb, E. M. (1989). Farmer sources and uses of information. Agribusiness, 5(5), 465-476. http://dx.doi.org/10.1002/1520-6297(198909) 5:5<465::AID-AGR2720050505>3.0.CO;2-6

Hagstrom, J. (2008). USDA to clarify country-of-origin labeling for U.S. meat. CongressDaily. Retrieved from http://www.nationaljournal.com/congressdaily/ cdp 20080922 3606.php

Juric, B., \& Worsley, A. (1998). Consumers' attitudes towards imported food labels. Food Quality and Preference, 431-441. http://dx.doi.org/10.1016/S0950-3293(98)00027-5

Kay, S. (2008a, September). COOL's devilish details. Beef, 64.

Kay, S. (2008b, September). Will MCOOL hurt ground beef sales? Beef, 14 .
Krejcie, R. V., \& Morgan, D. W. (1970). Determining sample size for research activities. Educational and Psychological Measurement, 30, 607-610.

Krissoff, B., Kuchler, F., Nelson, K., Perry, J., \& Somwaru, A. (2004). Country-of-origin labeling: Theory and observation. Electronic Outlook Report from the Economic Research Service. Retrieved from http://74.125.155.132/scholar?q= cache:Aoovdn R xwJ:scholar.google.com/+ country + of + origin + label + krissoff\&hl=en\&as $\mathrm{sdt}=2000$

Loureiro, M. L., \& Umberger, W. J. (2003). Estimating consumer willingness to pay country-of-origin labeling. Journal of Agricultural and Resource Economics, 28(2), 287-301.

Loureiro, M. L., \& Umberger, W. J. (2007). A choice experiment model for beef: What U.S. consumer responses tell us about relative preferences for food safety, country-of-origin labeling, and traceability. Food Policy, 32, 496-514. http://dx.doi.org/10.1016/j.foodpol.2006.11.006

Lynn, J. (2009, October 23). U.S. blocks Canada/Mexico call for WTO panel in meat row. Reuters. Retrieved from http://www.reuters.com

Naile, T. L. (2006). Editor preferences for the use of scientific information in livestock publications. Unpublished master's thesis, Oklahoma State University, Stillwater, OK.

Opara, L. U. (2003). Traceability in agriculture and food supply chain: A review of basic concepts, technological implications, and future prospects. Food, Agriculture \& Environment, 1(1), 101-106.

Quittner, J. (2007, August). Where's the food from? Business Week Online. Retrieved from http://www.businessweek.com

Rogers, E. M. (2003). Diffusion of innovations ( $5^{\text {th }}$ ed.). New York: A Division of Simon \& Schuster, Inc.

Schupp, A., \& Gillespie, J. (2001). Consumer attitudes toward potential country-of-origin labeling of fresh and frozen beef. Journal of Food Distribution Research, 33(1), 161-171.

Siegrist, H. (2009). Country-of-origin labeling criteria not a simple formula. Retrieved from www.newarkadvocate.com

Srivastava, L. (2003). Country-of-origin labeling. Retrieved from http://www2.parl.gc.ca/content/ LOP/ResearchPublications/prb0302-e.pdf 
Talbot, R. (2009, March 16). Country of origin labeling law good for US cooks. Suite101. Retrieved from http://cookingresources.suite101.com/article.cfm/ country of origin labeling law good for us cooks

U.S. Census Bureau. (2002). U.S. Summary: 2000. Washington, D.C.: Government Printing Office.

U.S. Census Bureau (2009). 2009 population estimates. Washington, D.C.: Government Printing Office.

U.S. Department of Agriculture. (2008a). COOL implementation: Legislative history and status of rulemaking. Retrieved from http://www.ams.usda. gov/AMSv1.0/getfile?dDocName=STELPRDC50 71922

U.S. Department of Agriculture. (2008b). Country of origin labeling. Retrieved from http://www.ams. usda.gov/AMSv1.0/ams.fetchTemplateData.do?te mplate $=$ TemplateM\&navID $=$ CountryofOriginLabe ling\&rightNav1 $=$ CountryofOriginLabeling\&topNa $\mathrm{v}=$ \&leftNav $=$ CommodityAreas\&page $=$ CountryOf OriginLabeling\&acct $=$ cntryoforgnlbl
U.S. Department of Agriculture (2009a). Country-oforigin labeling final rule. Retrieved from http://www.ams.usda.gov/AMSv1.0/getfile? $\underline{\mathrm{dDocName}=\text { STELPRDC5074925 }}$

U.S. Department of Agriculture (2009b). U.S. beef and cattle industry: Background statistics and information. Retrieved from http://www.ers. usda.gov/news/bsecoverage.htm

U.S. Department of Agriculture (2010). Livestock and meat trade data. Retrieved from http://www.ers. usda.gov/Data/MeatTrade/LivestockMeat Yearly.htm

Wadud, S. E., Kreuter, M. W., \& Clarkson, S. (1998). Risk perception, beliefs about prevention, and preventative behaviors of farmers. Journal of Agricultural Safety and Health, 4(1), 15-24.

Zoomerang. (2010). Retrieved from http://www.zoomerang.com/online-panel 


\section{Appendix:}

\section{Instrument}

\section{U.S. consumer perceptions of food buying and handling}

Created: July $062009,8: 52 \mathrm{AM}$

Last Modified: July 06 2009, 8:52 AM

Design Theme: Basic Blue

Language: English

Button Options: Labels

Disable Browser "Back" Button: False

\section{U.S. consumer perceptions of food buying and handling}

Question 1 - Yes or No

In regard to food buying, do you know what $\mathrm{COOL}$ stands for?

Y Yes

No

If Yes, please describe.

Question 2 - Yes or No

Do you or anyone in your household eat beef, poultry, pork or other meat products?

Y Yes

No [Skip to 33]

Question 3 - Choice - Multiple Answers (Bullets)

In the past month, which of the following beef products have you purchased? (Check all that apply)

Ground Beef

$\square$ Roast

$\square$ Steak

$\square$ Stew Meat

$\square$ Other, please specify.

Question 4 - Choice - One Answer (Bullets)

How often do you purchase ground beef from a grocery store, supermarket, or related retailer each month?
Never
Once
2-5 times
More than 5 times

Question 5 - Choice - One Answer (Bullets)

How often do you purchase a beef product (other than ground beef) from a grocery store, supermarket, or related retailer each month?
Never
Once
2-5 times
More than 5 times 
Question 6 - Choice - One Answer (Bullets)

How often do you eat ground beef in your home each month?
( Never
Once
2-5 times
(1) More than 5 times

Question 7 - Choice - One Answer (Bullets)

How often do you eat beef (other than ground beef) in your home each month?
Never
Once
2-5 times
More than 5 times

Question 8 - Choice - One Answer (Bullets)

How often do you read food labels when purchasing ground beef for consumption?
Never
Seldom
Often
Always

Question 9 - Choice - One Answer (Bullets)

How often do you read food labels when purchasing a beef product (other than ground beef) for consumption?
Never
Seldom
Often
Always

Question 10 - Rating Scale - Matrix

How important are each of the following parts of a ground beef label to you?

a. Brand

b. Country-of-origin

c. Freshness date

d. Handling statement

e. Ingredients

f. Lean to fat

g. Nutrition information

h. Organic/Natural

i. Price

j. USDA inspection legend

$\mathrm{k}$. Weight of product

Not at
importa
0
0
0
0
0
0
0
0
0
0
0

O

\section{2}

O

O

O

O

O

O

O

O

O

O

$\begin{array}{ccc}\begin{array}{c}\text { Somewhat } \\ \text { important }\end{array} & 4 & \text { Very important } \\ 0 & 0 & 0 \\ 0 & 0 & 0 \\ 0 & 0 & 0 \\ 0 & 0 & 0 \\ 0 & 0 & 0 \\ 0 & 0 & 0 \\ 0 & 0 & 0 \\ 0 & 0 & 0 \\ 0 & 0 & 0 \\ 0 & 0 & 0 \\ 0 & 0 & 0\end{array}$




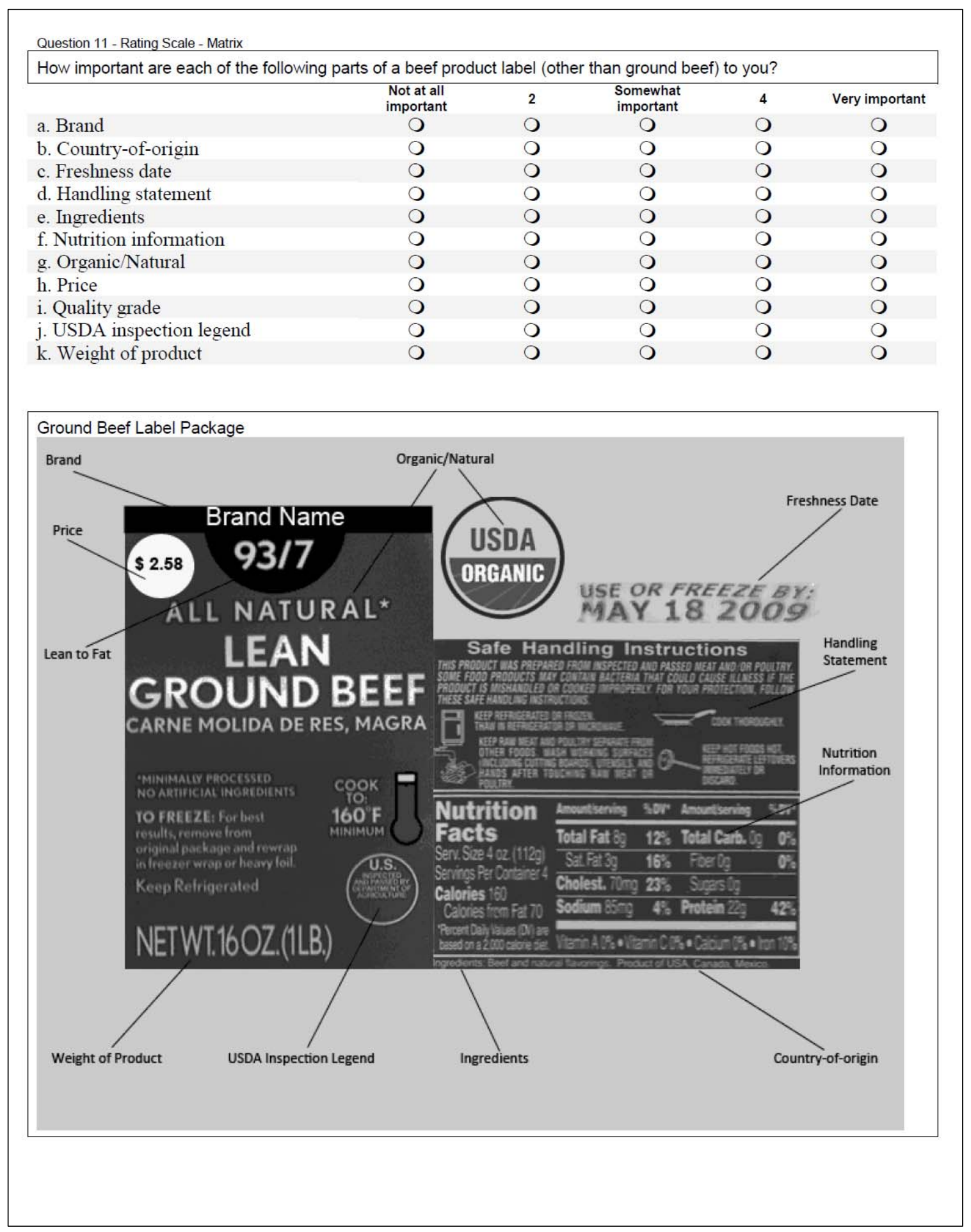


Heading

Based on the above FDA-approved label package for ground beef, choose your preference for the following questions:

Question 12 - Choice - One Answer (Drop Down)

What is the most important to you?
Brand
Country-of-origin
Freshness date
Handling statement
Ingredients
Lean to fat
Nutrition information
O Organic/Natural
Price
O USDA inspection legend
Weight of product

Question 13 - Choice - One Answer (Drop Down)

What is the second most important to you?
Brand
Country-of-origin
Freshness date
Handling statement
Ingredients
() Lean to fat
Nutrition information
O Organic/Natural
Price
USDA inspection legend
Weight of product

Question 14 - Choice - One Answer (Drop Down)

What is the third most important to you?
Brand
Country-of-origin
Freshness date
Handling statement
Ingredients
Lean to fat
Nutrition information
O Organic/Natural
Price
USDA inspection legend
Weight of product 


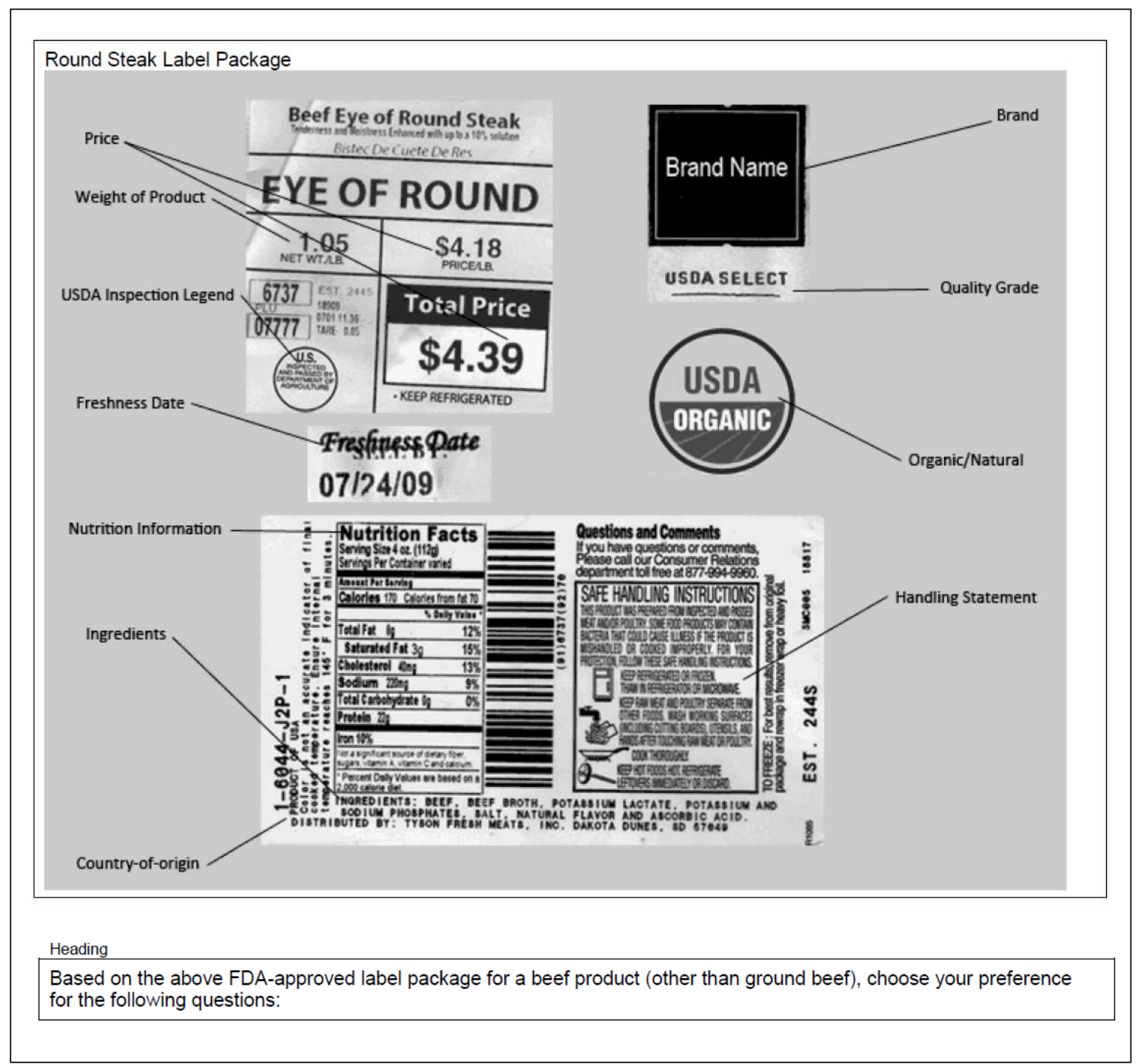


Question 16 - Choice - One Answer (Drop Down)

What is the most important to you?

Brand

Country-of-origin

- Freshness date

Handling statement

Ingredients

Nutrition information

O Organic/Natural

Price

() Quality grade

USDA inspection legend

Weight of product

Question 17 - Choice - One Answer (Drop Down)

What is the second most important to you?

Brand

Country-of-origin

Freshness date

Handling statement

Ingredients

Nutrition information

- Organic/Natural

Price

() Quality grade

USDA inspection legend

Weight of product

Question 18 - Choice - One Answer (Drop Down)

What is the third most important to you?

() Brand

Country-of-origin

Freshness date

Handling statement

Ingredients

Nutrition information

Organic/Natural

Price

Quality grade

USDA inspection legend

Weight of product

Question 19 - Choice - One Answer (Drop Down)

What is the least important to you?
Brand
Country-of-origin
- Freshness date
Handling statement
Ingredients
Nutrition information
O Organic/Natural
Price
Quality grade
$\bigcirc$ USDA inspection legend
Weight of product 


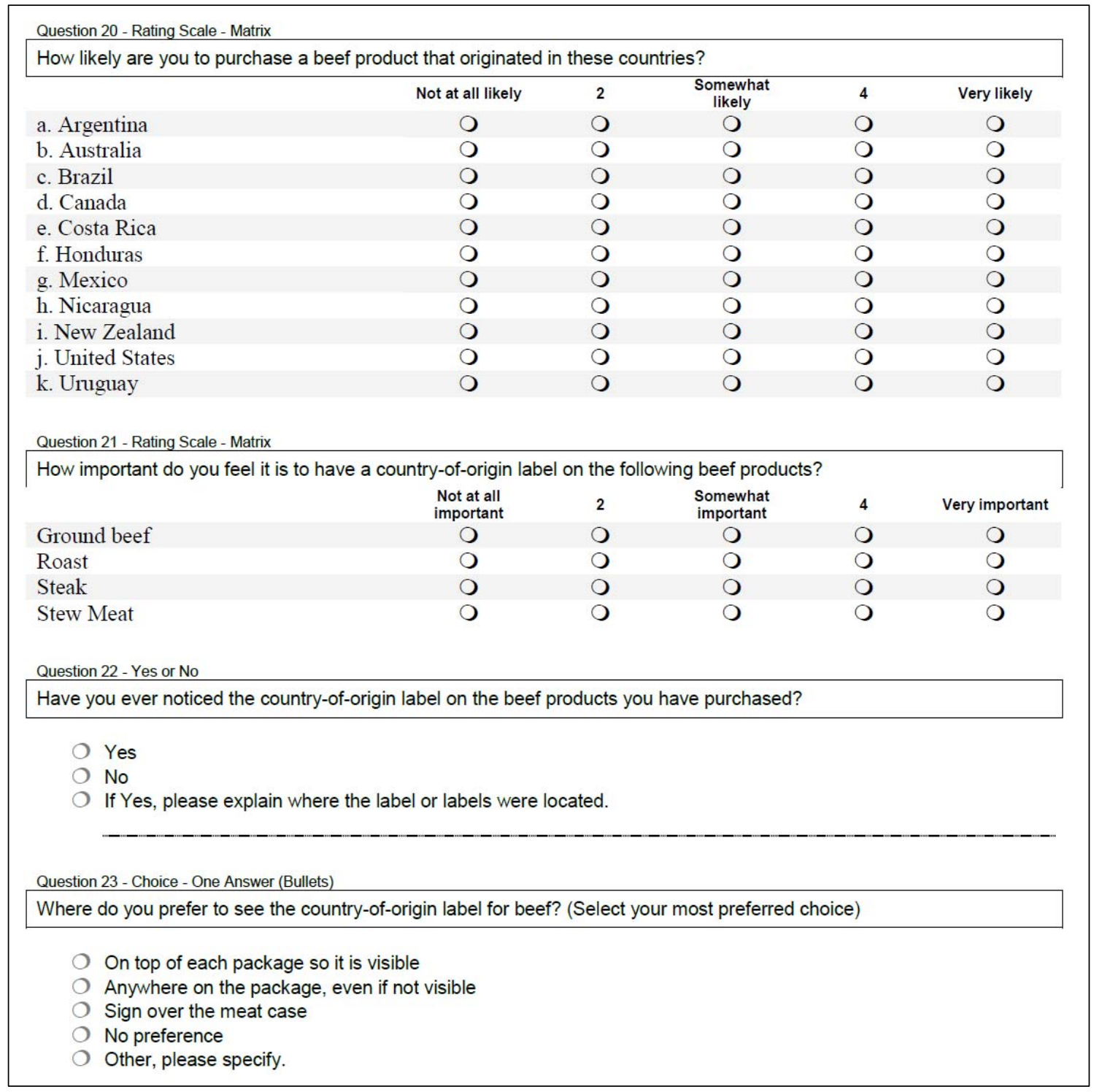


Question 24 - Choice - Multiple Answers (Bullets)

Think about the last beef product you purchased. From what country or countries did this product originate? (Check all that apply)
$\square$ Argentina
- Australia
$\square$ Brazil
$\square$ Canada
$\square$ Costa Rica
$\square$ Honduras
- Mexico
$\square$ Nicaragua
$\square$ New Zealand
$\square$ United States
$\square$ Uruguay
$\square$ Don't Know
$\square$ Other, please specify

Question 25 - Choice - Multiple Answers (Bullets)

Where do you receive information to make your food purchasing decisions? (Check all that apply)

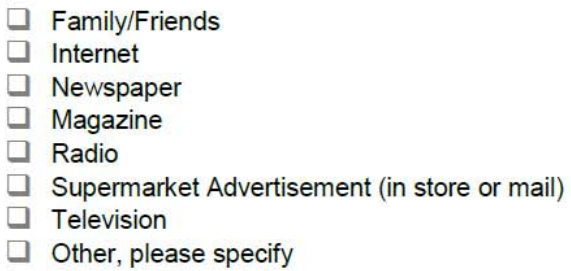

Question 26 - Rating Scale - Matrix

Please indicate how strongly you disagree or agree with the following statements regarding U.S.-origin (domestic) beef and imported beef. U.S.-origin beef.

b. I am concerned with the safety of U.S.-origin beef.

c. I am concerned with U.S.-origin beef carrying a disease.

d. I am concerned with the purity of imported beef.

e. I am concerned with the safety of imported beef.

f. I am concerned with imported beef carrying a disease.

g. U.S.-origin beef is higher quality than imported beef.

h. If I had the choice to purchase a U.S.-origin beef product or an

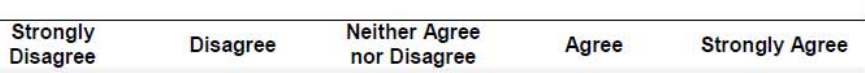
imported beef product at the same price, I would purchase the U.S. product. 


\begin{tabular}{|c|c|c|c|c|c|}
\hline $\begin{array}{l}\text { i. I would pay more for U.S.-origin } \\
\text { beef than imported beef. }\end{array}$ & $\mathrm{O}$ & $\mathrm{O}$ & 0 & $\mathrm{O}$ & 0 \\
\hline $\begin{array}{l}\text { j. I cannot tell the difference between a } \\
\text { U.S.-origin beef product and an } \\
\text { imported beef product without reading } \\
\text { the label. }\end{array}$ & $O$ & $O$ & $\mathrm{O}$ & O & O \\
\hline $\begin{array}{l}\text { k. The U.S. government assures } \\
\text { wholesomeness for both U.S.-origin } \\
\text { and imported beef. }\end{array}$ & $\mathrm{O}$ & $\mathrm{O}$ & $\mathrm{O}$ & $\mathrm{O}$ & O \\
\hline $\begin{array}{l}\text { 1. The U.S. government assures } \\
\text { cleanliness for both U.S.-origin and } \\
\text { imported beef. }\end{array}$ & O & 0 & 0 & O & $\mathrm{O}$ \\
\hline $\begin{array}{l}\text { m. U.S.-origin beef and imported beef } \\
\text { are often mixed (i.e., hamburger), so } \\
\text { they must be of equal quality. }\end{array}$ & $\mathrm{O}$ & $\mathrm{O}$ & $\mathrm{O}$ & $\mathrm{O}$ & O \\
\hline $\begin{array}{l}\text { n. I expect retailers to provide me with } \\
\text { the best beef available. }\end{array}$ & $\mathrm{O}$ & $\mathrm{O}$ & $\mathrm{O}$ & O & O \\
\hline $\begin{array}{l}\text { o. All beef products sold in grocery } \\
\text { stores and supermarkets should include } \\
\text { a country-of- origin label. }\end{array}$ & O & $\mathrm{O}$ & 0 & $\mathrm{O}$ & O \\
\hline $\begin{array}{l}\text { p. I would prefer that restaurants also } \\
\text { provide me with the country-of-origin } \\
\text { for beef products. }\end{array}$ & $\mathrm{O}$ & $\mathrm{O}$ & O & O & $\mathrm{O}$ \\
\hline $\begin{array}{l}\text { q. Country-of-origin labeling makes } \\
\text { beef more safe to eat. }\end{array}$ & 0 & $\mathrm{O}$ & $\mathrm{O}$ & $\mathrm{O}$ & O \\
\hline $\begin{array}{l}\text { r. I understand the concept of multi- } \\
\text { country-of-origin labeling. }\end{array}$ & $\mathrm{O}$ & $\mathrm{O}$ & $\mathrm{O}$ & $\mathrm{O}$ & O \\
\hline \multicolumn{6}{|l|}{ Question 27 - Rating Scale - Matrix } \\
\hline \multicolumn{6}{|c|}{ Please indicate how strongly you disagree or agree with the following statements regarding beef buying habits. } \\
\hline & $\begin{array}{l}\text { Strongly } \\
\text { Disagree }\end{array}$ & Disagree & $\begin{array}{l}\text { Neither Agree } \\
\text { nor Disagree }\end{array}$ & Agree & Strongly Agree \\
\hline $\begin{array}{l}\text { a. I will purchase ground beef of any } \\
\text { origin. }\end{array}$ & O & O & O & O & O \\
\hline $\begin{array}{l}\text { b. I will purchase ground beef with a } \\
\text { multi-country-of-origin label. }\end{array}$ & O & O & O & O & O \\
\hline $\begin{array}{l}\text { c. I will purchase other beef products } \\
\text { (i.e., roast, steak, stew meat) of any } \\
\text { origin. }\end{array}$ & O & O & O & O & O \\
\hline $\begin{array}{l}\text { d. I will purchase other beef products } \\
\text { (i.e., roast, steak, stew meat) with a } \\
\text { multi-country-of-origin label. }\end{array}$ & O & O & O & O & O \\
\hline
\end{tabular}


Question 28 - Rating Scale - Matrix

Please indicate your involvement or awareness level for the following questions.

$\begin{array}{lllll}\text { Not at all } & 2 & \text { Somewhat } & 4 & \text { Quite a lot }\end{array}$

a. How involved are you in the agricultural industry?

b. How involved are you in the beef industry?

c. How aware are you of the labeling policies of beef?

d. How aware are you about

mandatory country-of-origin labeling

(COOL) for beef?

$\begin{array}{ccccc}0 & 0 & 0 & 0 & 0 \\ 0 & 0 & 0 & 0 & 0 \\ 0 & 0 & 0 & 0 & 0\end{array}$

Question 29 - Choice - One Answer (Bullets)

How many times have you heard about mandatory country-of-origin labeling $(\mathrm{COOL})$ in the past year?

Never

O Once

2-5 times

More than 5 times

Question 30 - Choice - Multiple Answers (Bullets)

If you have heard about mandatory country-of-origin labeling (COOL), what sources provided you with the information? (Check all that apply)
$\square$ Family/Friends
$\square$ Internet
$\square$ Newspaper
Magazine
$\square$ Radio
$\square$ Supermarket Advertisement (in store or mail)
$\square$ Television
Don't Know
$\square$ Have not heard of COOL
$\square$ Other, please specify

Question 31 - Open Ended - Comments Box

What does mandatory country-of-origin labeling (COOL) mean to you?

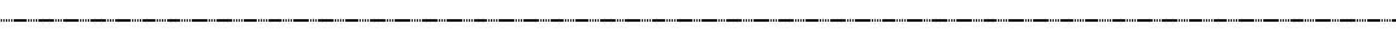

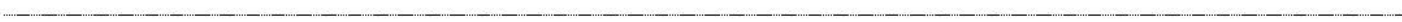

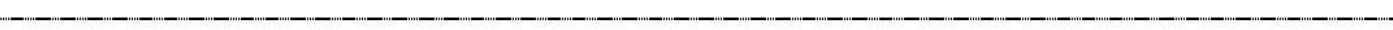

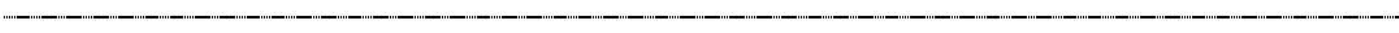

Question 32 - Open Ended - Comments Box

What do you believe is the purpose of mandatory country-of-origin labeling (COOL) in the United States? 
Journal of Agriculture, Food Systems, and Community Development ISSN: 2152-0801 online

www.AgDevJournal.com

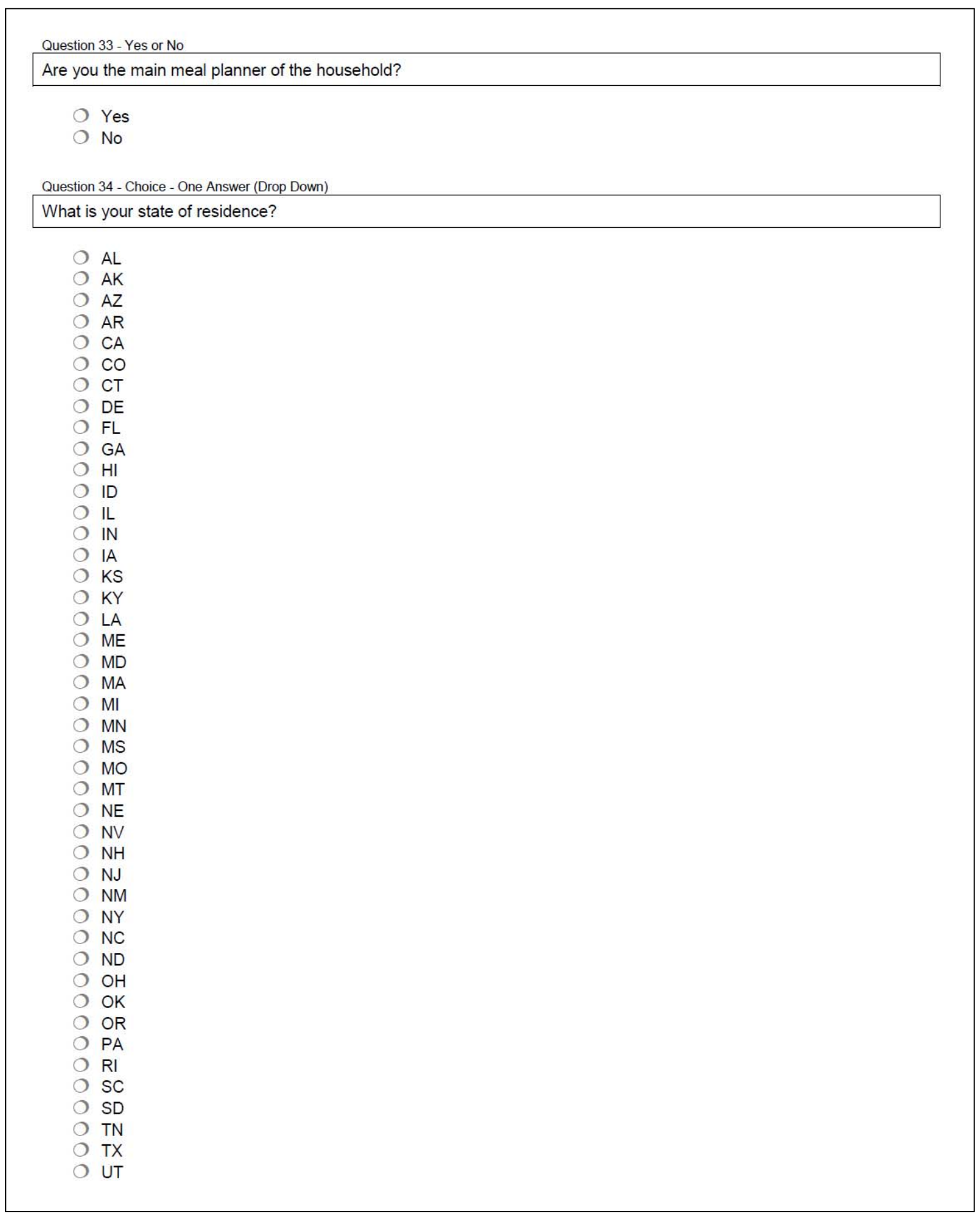




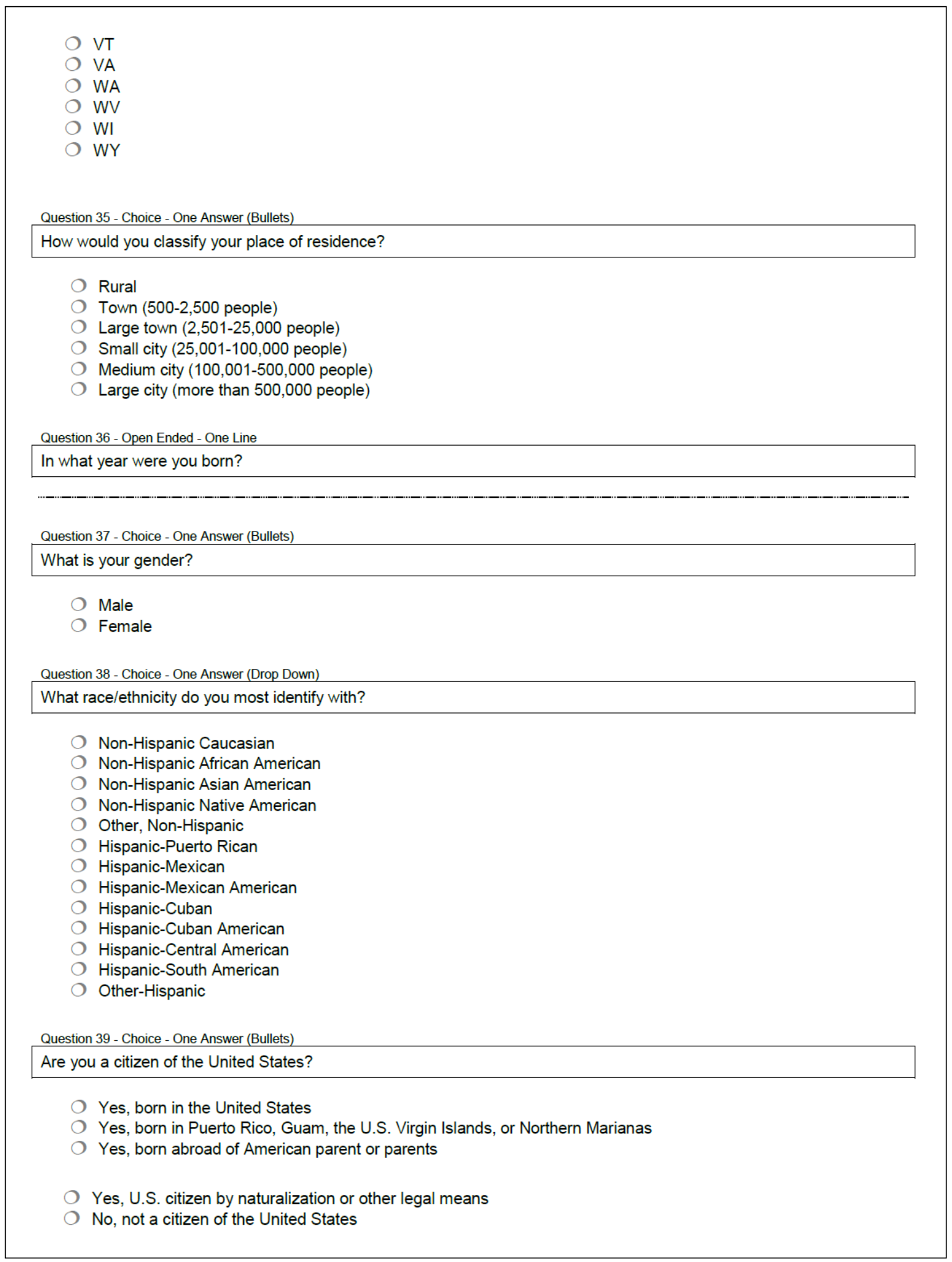


Journal of Agriculture, Food Systems, and Community Development ISSN: 2152-0801 online

www.AgDevJournal.com

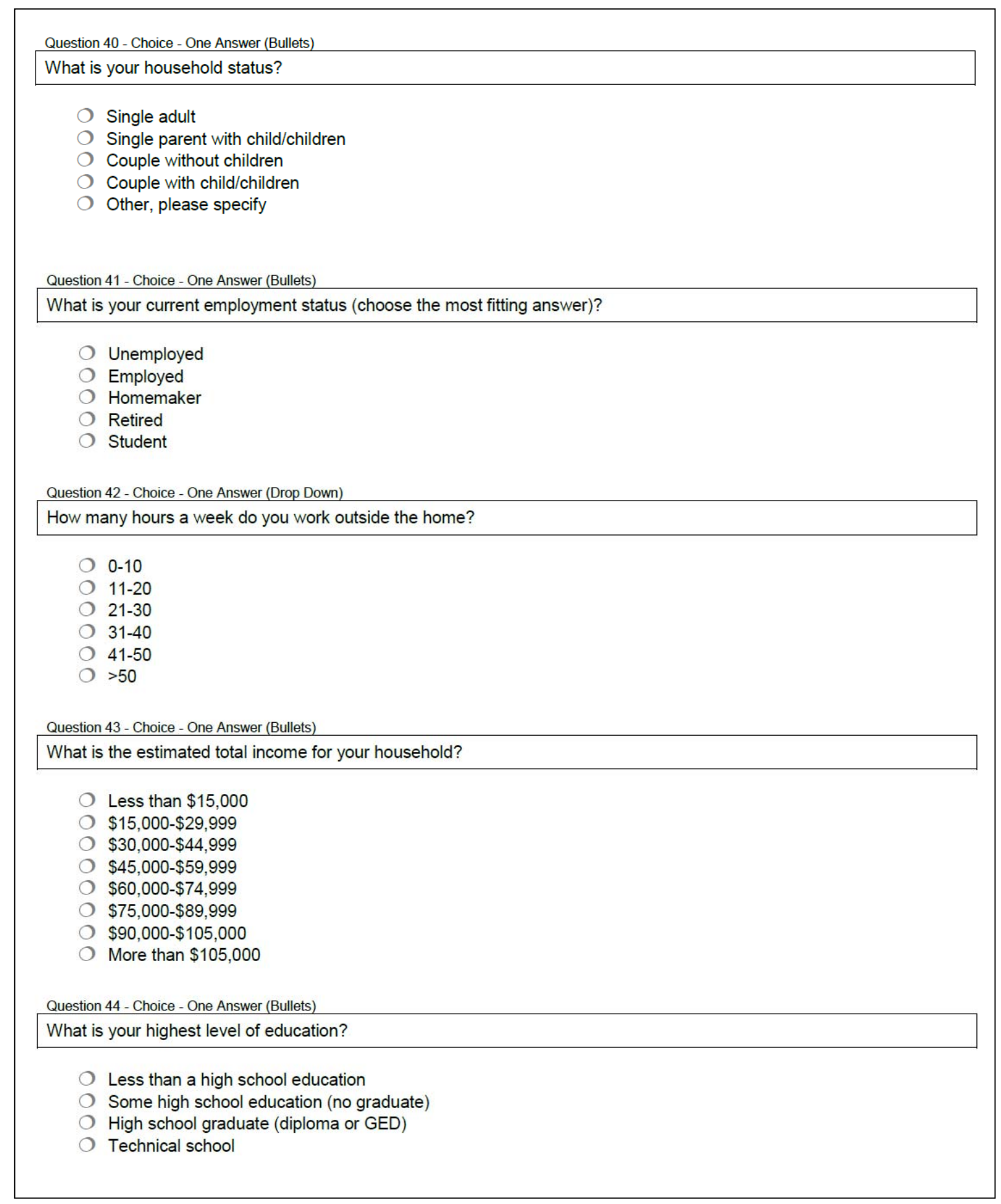


Journal of Agriculture, Food Systems, and Community Development ISSN: 2152-0801 online www.AgDevJournal.com

Some college education

O Associate's degree

Bachelor's degree

Master's degree

- Doctorate degree

End of survey 